\title{
Treatment Strategies for Reducing Damages to Lungs in Coronavirus and Other Lung Infections
}

(Preprint for comments, NOT published)

Jianqing $\mathrm{Wu}^{1}$, Ph.D., J.D. and Ping Zha ${ }^{2}$, M.D. (Chi. Med.)

Correspondence: tempaddr2@atozpatent.com

1. End the Incurable Era (Independent researcher for cause), P. O. Box 689, Beltsville, MD 20704. www.igoosa.com.

2. Independent Researcher (Not affiliated with any entity), can be reached by using the above address.

Keywords: coronavirus COVID-19, SARS, MERS, viral reproduction, immune response, lung infection influenza, deep breathing, diet, emotional stress, lifestyle

\begin{abstract}
We conducted many model simulations to understand the causes of the damages of coronavirus (COVID-19) to lung tissue and constructed a diagram showing apparent viral reproduction, immune response and damage accumulation curves. We found that lung damages include virus-caused damage, tissue damage caused by immune responses and tissue damage caused by accumulated wastes. The virus-caused damage is proportional to the phase lag between the viral reproduction curve and the delayed adaptive immune response curve, while waste-induced damage is attributed to imbalance in removing viral, cellular and metabolic by-products. We found that treatment strategies should slow down viral reproduction and speed up immune response, and improve blood microcirculation in the lungs. Consistent with the strategies, measures are taken to void direct lung infection, strengthen innate responses, promote immune responses, dilute viral concentration in lung tissue, maintain waste removal balance, protect heart and kidneys, control other infections, avoid allergic reactions and other inflammation, etc. We show that medical, dietary, emotional, lifestyle, environmental, mechanical factors, etc. may be simultaneously used to mitigate lung damages and prove that multiple factor health optimization method is magnitudes more powerful than a single factor treatment. Such a method does not depend on molecular specificity and can be used in parallel to antiviral drugs.
\end{abstract}

\section{INTRODUCTION}


The outbreak of SARS in 2003 led to a near pandemic with 8096 cases and 774 deaths reported worldwide, resulting in a fatality rate of $9.6 \%$ [1]. Since the outbreak of MERS in April 2012 up until October 2018, 2229 laboratoryconfirmed cases have been reported globally, including 791 associated deaths with a case-fatality rate of 35.5\% [2]. Viruses emerge and re-emerge globally. In the past, we have witnessed outbreaks of Ebola, Chikungunya, and Zika [3]. With each new outbreak, lives are lost, and economy was disrupted. The handling of such outbreaks is inherently difficult. It is hard to decide what must be done. It is argued that World Health Organization was slow in responding the 2014-2015 Ebola outbreaks [4].

The emerging coronavirus (COVID-19) outbreak in Wuhan is caused by a new type of coronavirus distantly related to the SARS coronavirus (SARS-CoV) [5]. With an increasing number of new cases reported in China and other countries, the world is seeking cures for the virus. At this point in time, 27 countries have confirmed coronavirus cases, and 12 countries have reported suspected cases, the outbreak has already placed the world on a public health alert, and adversely affects business, traveling, imports and exports, etc. Given the suspected long viral survival time, full containment depends on temperature.

Containing the outbreak by breaking chain of infection seems very hard for this virus. The war against lung viral infections has been fought for some time [6] and there is no simple cure for various reasons. First, RNA viruses have a highly error-prone polymerase used for genome replication, and individual RNA genomes within a species generally differ by many nucleotides from the average genome sequence [7]. When its genetic composition changes, existing drugs may lose effectiveness. This new virus adds another disease onto endemic human coronaviruses. Two other coronaviruses, OC43 and 229E, were discovered in the 1960s but had circulated in cows and bats, respectively, for centuries and other two, HKU1 and NL63, were discovered after the 2003-2004 SARS outbreak, also after circulating in animals [8]. Second, after a large number of human beings have been infected, some of them may carry the virus in a dormant state. When they are in poor health conditions, the virus may erupt.

Finally, drugs do not work on every person due to drug resistance and unique personal physiological conditions [9]. The early reports reflect that the virus is poorly responsive to existing antiviral drugs [10]. At this point, CDC still cannot offer cure. The lack of cure may still happen to a small number of individuals even if good drugs or effective vaccines are found. For those reasons, we explore alternative and complementary remedies that do not depend on chemical specificity and that can be used when no drug can cure the infection.

\section{ANALYSIS AND RESULTS}

To explore multiple factors approach for the COVID-19 disease, we first examine how the virus reproduces and how the immune system responds. 


\section{A. Phase Lag Between Viral Development and Immune Responses}

The risk of the virus lies in the phase lag between viral reproduction process and adaptive immune responses. This problem is particularly severe when initial infection takes place in the lungs.

The epithelial surface of the alveoli is composed of alveolar type I and type II cells [11]. The lung cells form a thin layer for minimizing diffusion distance between the alveolar air space and pulmonary capillary blood. It is expected that the virus attaches and enters the cells [12]. After a virus has entered into an epithelial cell, it may stay dormant for some time before it starts replicating. After the virus has reached to certain number or volume fraction, the virus is released. Some of the viruses may get into bloodstream while some may infect nearby cells and repeat the same process. The viruses or their proteins reach secondary lymphoid organs (SLOs) to activate the adaptive immune system [13]. The activated B cells generate clones. While the exact time for completing the virus reproduction cycle is unknown for this virus, the reproduction time for other viruses such as bacteriophage is from tens minutes to several hours [14]. Unless, the host cells can hold the virus in a dormant state, the virus can quickly infect cells by cell-to-cell spread.

\section{Model for a single infection point in a lung}

If the virus infects one alveolus, the virus may quickly damage the alveolus. The air space of alveolus is in close proximity $(0.2 \mu \mathrm{m})$ to pulmonary capillaries [11]. Air is exchanged around 10 to 15 times a minute. If the virus infects any part of the alveolus, it may damage it in several minutes to hours based on model parameter. There are about 600 million alveoli in the lungs. In an adult, the lungs weigh approximately $1000 \mathrm{~g}$. Lung volume is about $6000 \mathrm{~mL}$. The height of a normal adult lung is 24 to $27 \mathrm{~cm}$. If a single point is infected by the virus, the viruses would pass a distance of $12 \mathrm{~cm}$ from the center to the edge. If the virus transmits by cell-cell direct contact, the virus would have to travel through about 12000 layers of cells assuming that each layer is $10 \mu \mathrm{m}$ thick. If the latent time is 10 to 60 minutes, the total time would be 2000-12000 hours (83-500 days). If adaptive immune response starts working in 4 to 7 days, a single point infection can cause only limited damage. This model dose not take into account potentially collective infection mechanisms, viral concentration, and virus spreading by blood.

After the alveoli are damaged, thet cannot support the bronchial tubes. The tubes collapse and cause a blockage, which traps air inside the lungs. Because there are fewer working alveoli, less oxygen will be able to move into the bloodstream. The lung function is diminished.

2. Model for multiple-point simultaneous infections

Adult lungs have about 600 million alveoli. For the lungs to reach a disability or death threshold, the damages must involve a sufficient number of alveoli. If infection starts with a single point, virus spreads by cell-to-cell- 
transmission or redistribution of exhaled viral particles. There is no natural law that limits infection points to one single point. If infection starts at multiple points, the virus can cause the same level damages in shorter time. The more infection points in the lungs, the more serious damages can the virus cause. If the viruses stay in a dormant state, they do not get into blood in a meaningful number and thus fail to activate adaptive immunity. After the viruses change from a dormant state to a reproduction state, they can spread by cell to cell contact, and quickly damage infected alveoli in substantially same time. In the worst scenario, the virus may damage the whole lungs in a few hours. In this model, the immune system is completely in dark without being aware of the viral invasion. The infected person may die within one or two days.

Kinetic differences are reflected in ample data. It generally takes 4-7 days to activate adaptive immunity and achieve detectable antibodies [15]. In infants infected with RSV virus, viral clearance is typically achieved within 3 weeks of infection onset [13]. Antibodies were not detected on some patients until 4 weeks later [16]. The median incubation period of MERS-CoV infection is 5 days, with the average time from onset of symptoms to hospitalization of approximately 4 days [17]. In contrast, SARS exhibited an incubation time of at most 10 days, with symptom onset occurring on 2-7 days post-exposure [18]. The estimated median incubation time of COVID-19 was 5.1 days mean incubation time was 5.5 days [19]. Considering incubation time distribution, symptoms could appear in 1 days and 14 days. MERS-CoV in the Saudi Arabia outbreak develops the disease after 6.2 days, and continued releasing the virus for 13.17 days on average. The incubation period as well as latent time reflect the time for viral reproduction and reach a level of damage. The time window for releasing virus at least in part reflects the delay in the adoptive immune response. The differences in incubation time may be in part due to the number of initial infection points and successive infections. The more infection points in the lungs, the faster and serious damages the virus can cause.

\section{A model for non-lung initiated infection}

If the virus enters into the body through the digestive track, a cut or any other locality, the virus goes through a longer process. Those infection routes result in a delayed infection of the lungs, and alters the outcome of the speed contest between viral reproduction and immune responses.

When infected cells release viruses from infected cells, some of released viral particles arrive at the lungs and some of them also arrive at secondary lymphoid organs at substantially same time. When the first batch of viruses reach the lung cells, the immune system has started activating B cells. The viral concentration at the lungs is very low; and so it is viral concentration in the secondary lymphoid organs.

An important factor is difference in viral concentration. In the model 1 , the initial virus concentration is high enough to infect the lung cells. The virus concentration carried in blood is diluted by blood. An adult weighing 150 to 180 
pounds should have about 1.2 to 1.5 gallons $(4,500$ to $5,700 \mathrm{~mL})$ of blood. If the first infected cell releases viruses into blood, the viral particles are diluted by the blood. We use half blood volume $2,550 \mathrm{~mL}$ to account for incomplete dilution or non-complete mixing. If the viral concentration from the releasing cell is used as a reference and the total cell volume is $1,764 \mu \mathrm{m}(3)$ (the mean volume), the total dilution factor for the virus is about $1.4 \times 10(12)$. By viral reproduction, more and more viral particles are released into blood. Assuming that the early infected site has a million virus-releasing cells, the virus concentration from the circulating blood would be still diluted by 1.5 million times. Actual concentration may be much lower because viruses are being destroyed by humoral immune response [20] while they are traveling. If the released viruses are not completely destroyed by immune responses, the concentration of viruses that has been brought by blood may be still diluted by millions of times.

4. Phase lags between lung-initiated and non-lung-initiated immune responses

An initial infection may be in the lungs or a non-lung tissue such as the digestive track. When an infection is initiated in a lung, the viruses can directly damage lung cells soon after they start reproduction cycles. They may start cellto-cell transmission without giving the immune system a meaningful signal. The immune system is not activated before at least some infected cells have released the viral content that has reached secondary lymphoid organs. Moreover, activation also depends on various conditions and existence of co-factors.

B cell activation occurs in the secondary lymphoid organs such as the spleen and lymph nodes [20]. Antigens such as protein from the virus activate B cells with the help of T-cell. B cell response to such antigens takes multiple days. Then activated B cells participate in a two-step differentiation process that yields both short-lived plasmablasts for immediate protection and long-lived plasma cells and memory B cells for persistent protection [21]. The first step, known as the extrafollicular response, occurs outside lymphoid follicles, but still in the SLO. Of the three B cell subsets, FOB cells preferentially undergo T celldependent activation while MZ B cells and B1 B cells preferentially undergo T cell-independent activation [21].

In a first step, activated B cells proliferate, undergo immunoglobulin class switching, and differentiate into plasmablasts that produce early weak antibodies mostly of class IgM [22]. In a second step, activated B cells entering a lymphoid follicle and forming a germinal center, which is a specialized micro environment where B cells undergo extensive proliferation, immunoglobulin class switching, and affinity maturation directed by somatic hypermutation [23]. Both T cellindependent activation and $\mathrm{T}$ cell-dependent activation are expected at the same time scale for viral spreading.

When the lungs are infected initially, the virus has not reached the secondary lymphoid organ yet; and even if some viruses get into blood, they have been diluted by blood by millions to a billion times. It is highly unlikely for such viruses to reach a required concentration that can reliably activate $\mathrm{B}$ cells in a 
meaningful way. Second, B cell activation often requires co-factors and various conditions [21, 22, 23]. Thus, even if a sufficient number of viruses or viral proteins are around a B cell, the B cell may be not activated immediately due to missing co-factors or breached conditions. Finally, the cloning process naturally takes time for the antibody to reach a level that has a practical meaning. Multiple-day delays in production antibody are recognized by a consensus.

5. Infections by viruses carried in blood and by cell-cell direct contact

In direct cell-to-cell infection, the high viral population or concentration in the lung cells can quickly infect and kill lung cells. The discharges from a releasing cell may contain thousands of copies of viruses, which have a high chance to infest its neighbor cells. Some discharges that are close to capillaries or good blood flow path are diluted by blood, and may become less lethal to other tissues. While it is not known what is the minimum concentration required for infecting cells, it is unlikely that highly diluted viruses can infect host cells $[21,22,23]$. The infested cells repeat the same process and destroy the lungs. However, viruses from blood do not have same chances to infect lung cells because they are highly diluted and under immune attacks. When more and more viruses are released from initially infected cells, the viral concentration in blood arises. However, the antibody concentration increases even faster and ultimately brings the virus population under control.

Fluid from blood dilutes amino concentrations and lower viral activities frequencies in the lungs. During viral replication, a large number of proteins assemble around the viral nucleic acid to form a protein shell. It was found that the palmitate adducts on coronavirus $\mathrm{S}$ proteins are necessary in assembly and also in positioning the assembled envelope proteins for maximal infectivity. Intuitively, a good blood circulation in the lung tissue can cause flow disturbance inside lung cells and thus hinders the formation of the protein assembly and also dilutes palmitate. Good blood flow also affects host cell stress responses [24].

6. A system diagram for reducing damages to lungs

Based on the behaviors of the above models, all findings are shown in Figure 1. 

A: Area A reflects viral damage
D1: Reversible damages
$B$ : Area $B$ represents total wastes (include all damages)
D2: Permanent damages (mainly due to necrosis)

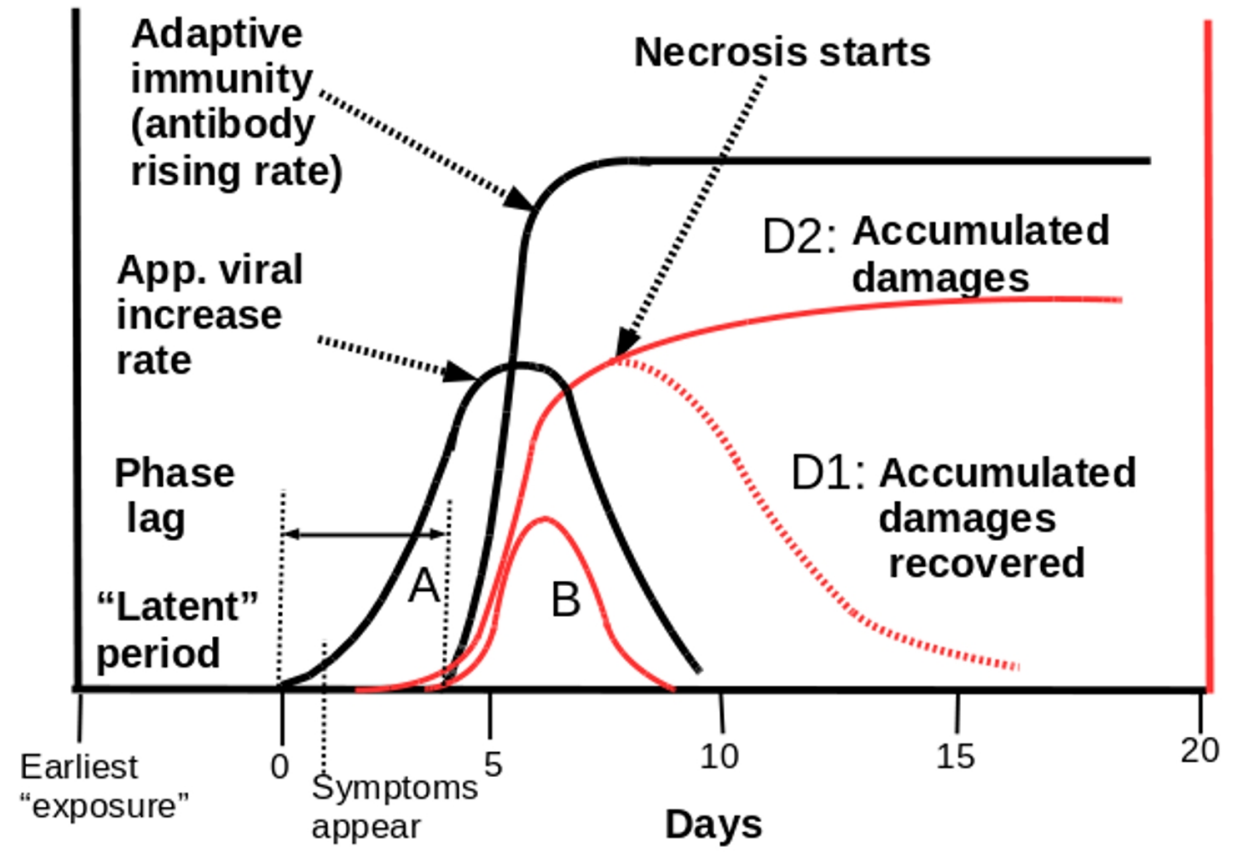

Figure 1 shows that the virus starts reproducing after exposure. The antibody production starts after a longer delay. After B-cell activation, antibody concentration rises rapidly. The immune system starts bringing down the viral reproducing speed. The size of area A reflects the total viral population and the direct damages by the virus to the lungs. After the war between the immune system and the virus starts, the tissue produces wastes-anything that should not be there - at rates which first increase, then level off, and finally decline consistent with reduced virus population. The area B reflects total wastes from the immune response. The accumulated damages denoted by $\mathrm{D}$ and followed by D1 and D2. If blood circulation in the tissue is maintained, the damage is irreversible as shown in D1. However, if the produced wastes are accumulated, they cause and aggravate tissue inflammation and tissue swelling, which eventually lead to tissue necrosis. As shown in D2, the damages from tissue necrosis are largely irreversible.

The difference in infection routes and the phase lag between the virus reproduction in the lungs and the immune response is the main reason for disparity in observed disease severity. This difference implies right treatment strategies. Sound measures should be directed to slowing down viral reproduction speed and increasing immune response. The strategies are using everything that can be found to reduce areas of A and B, and taking additional measures to maintain the waste removal balance to prevent tissue necrosis.

\section{B. Damages Caused by Immune Responses}


If the immune response is boosted up before the virus has caused sufficient damages, the disease may resolve quickly. However, if the virus has invaded into and infected a sufficiently large portion of lung cells, the immune response will wage a large scale war against the virus and infected cells. The immune induced inflammation results in massive cellular waste, viral debris and metabolic products. If the wastes are not promptly removed, they aggravate inflammation and tissue swelling. The swelling further impairs micro circulation efficiency in lung tissue.

\section{The main battles against the virus}

The virus damages lung cells directly. This damage is controlled by altering viral reproduction cycle or the size of A in the Figure. In the belated war against the virus, the immune system kills infected cells and virus in the following ways [15, 20-22].

1. Cytotoxic T cells kill lung cells that are infected with viruses by releasing toxic mediators. Cytotoxic $\mathrm{T}$ cells have specialized proteins on their surface that help them recognize infected cells.

2. The virus can also be cleared by antibodies before they get the chance to infect a cell. Antibodies recognize viruses, bind to them, cause virus particles to stick together as agglutinated viruses. Phagocytic cells engulf and destroy the virus.

3. Antibodies can also activate the complement system, which opsonises and promotes phagocytosis of viruses. Complement can also damage the envelope (phospholipid bilayer) that is present on some types of virus.

4. Interferons prevent replication of viruses by directly interfering with their ability to replicate within an infected cell. They also act as signaling molecules that allow infected cells to warn nearby cells of a viral presence - this signal makes neighboring cells increase the numbers of MHC class I molecules upon their surfaces so that $\mathrm{T}$ cells surveying the area can identify and eliminate the viral infected cells.

After viruses are killed, the end products are cellular debris, viral debris, and metabolic by-products. If the infection is severe, the amount of the wastes from immune responses is large. The viral activity, the immune response, and the wastes all cause distress to lung cells. In this phase, the virus population is in decline, but the wastes rise. If the wastes are not removed, blood micro circulation is slowed or blocked, the lungs are unable to maintain the required speeds for antibodies migrate from blood into the lungs, and large $\mathrm{T}$ cells cannot migrate into the lung cells. Therefore, we will examine how waste removal rates affect the lung tissue.

2. A model for maintaining the waste removal balance 
Maintaining the waste removal balance is critically important in mitigating lung damages. In any given time, if the viral-caused waste is increased by $\mathrm{dN}$ and if the lungs do not remove increased waste completely, it is accumulated. The total amount of accumulated wastes is the sum of surplus wastes in all time increments. The imbalance in wastes removal has severe adverse impacts if the imbalance exists in an indefinite time. This balance requirement is true to viral particles.

However, viral reproduction speeds fluctuate. The invaded viruses first stay dormant for a period of time. Then, they pick up their reproduction speeds slowly, and then grow exponentially. The apparent reproduction speed is expected to slow down and level off when the virus has consumed required biological resources. Despite the fluctuation, one requirement is that the lungs remove all produced wastes including virus debris, and related by-products promptly. If they are not removed through blood circulation, they must be brought out by other means. Coughing, running nose, and other discharges can remove extra wastes if blood circulation would not. In patients with severe lung distress, even those secondary means are unavailable due to the weakness caused by the disease.

The crucial importance of maintaining the waste removal balance is implied in the steady state theory. Adverse outcomes from failure to maintain the input and output balance are universally important for complex machines such as cars and planes. If the heat generated in each work cycle is more than that removed, the engine eventually is ruined by accumulated heat.

Even just a 1\% imbalance can result in damages quickly. For a given lung tissue that can produce wastes at $100 \%$ per hour. If the tissue can remove all of them, the tissue can keep the original waste amount. If the lungs can remove $99 \%$ of produced wastes but fail to remove $1 \%$ in each hour, the tissue would retain the wastes equivalent to the full amount generated in one hour after one hundred hours (four days). The accumulated wastes may cause tissue damage, diminish immune function, and increase immune damages. The immune system attack virus, resulting in viral and cell debris in the lungs. If the wastes as well as some viruses are brought to and dissipated in blood, some of the damages that would take place in lungs will take place in other body parts that are not vital to life.

The speed at which lungs are damaged can be rapidly sped up by vicious cycles caused by the lungs, heart and kidneys interactions. The wastes intoxicate lung tissue, and cause severe tissue inflammation and swelling [25, 26, 27]. The swelling of lung tissue further degrades blood circulation efficiency in the lungs and thus impair oxygen uptake. The lack of oxygen thus impairs renal function [28] and heart function [29, 30, 31, 32]. The diminished blood circulation in lungs results in a further reduced lung capacity for removing metabolic products, viral and cellular debris, and reduces lung ability to get oxygen. When blood circulation in the lungs is dominated by much slower diffusion processes, reduced oxygen saturation adversely affects the body. Eventually, the heart has 
reduced capacity of pumping, the kidneys have reduced capacity to process wastes, and the liver cannot effectively filter the blood and detoxify chemicals and drugs. As long as this waste removal balance is not restored, the body viciously degrades to the point that one or more organs fail. Due to the vicious interactions, the lungs may fail to remove $1 \%$ of produced wastes in the first hour, $2 \%$ in the tenth hour later, $3 \%$ in the twentieth hour.

One possible strategy is to slow down immune response. The immune system augments initially very slowly, and raises antibody producing speed exponentially. However, the final resolution of the disease depends on immune response. So, slowing down immune response is not a sound strategy (except in life-threatening cases). Besides, the body normally scales down the antibody production speeds quickly after the infection is brought under control. This leaves only one strategy that can be used in the clinical setting: removing antigens and all metabolic wastes from the tissue fast enough to maintain the balance. Other sources of inflammation must be addressed because they are presumed to aggravate lung damages.

\section{Controlling Points Are the Phase Lag and Lung Micro-circulation}

To reduce the risk of death, two control points are to reduce the phase lag between viral reproduction and immune response (the areas A and B), and improve blood micro-vascular circulation in the lungs. Despite lack of direct evidence for the COVID-19, host cell physiological state is presumed to affect the viral reproduction speed and the immune response speed in humans.

Area A as well as the phase lag must depend on the relative concentrations of the viruses in the infection site, manner of infection, re-infection of hostgenerated virus, and successive exposure and infection of the same virus. Virus infection depends on contact chances. In bacteriophage, host quantity, which dictates the average time for a phage to find and infect an uninfected host, and the host physiological state affects the rate by which the phage progeny are assembled/matured [14]. A body of studies establishes that that intra-host viral population diversity, as reflected in collective infection, co-infection, and cooperative infection, is a prerequisite for a virulent infection [32, 33, 34, 35, 36, 37]. Serial passage of a virus in laboratory animals is often used to increase pathogenicity of the virus for that host in order to generate a laboratory model of the disease [38, 39]. Viral spread is often mediated by structures as vehicles for groups of viral genomes, such as polyploid virions, aggregates of virions, virioncontaining proteinaceous structures, secreted lipid vesicles, and virus-induced cell-cell contacts [32]. The requirement of high concentration is reflected in the multiplicity of infection concept, which has been traditionally defined as the ratio of infectious viral particles to susceptible cells in a given space or alternatively, the average number of viral genomes that initiate an infection [32]. The codelivery of multiple viral genomes to the same target cell can be further facilitated by direct contacts between cells [32, 40-43]. Multi-genome infectious structures may promote mutually beneficial interactions between different 
variants of a virus at the intracellular level $[44,45]$. RNA viruses have a highly error-prone polymerase used for genome replication, and individual RNA genomes within a species generally differ by many nucleotides from the average genome sequence [7]. More viral units must provide infection.

The most important viral spreading route within the body is cell-to-cell transmission. This mechanism implies that apparent viral spreading speed depends on the infection points, infection point distribution and host interactions. Even though details for COVID-19 are unknown, its mechanism and future knowledge can be used to alter apparent viral reproduction speed. Effective cell-to-cell transfer can occur in the absence of specific cell signaling structures if viral budding is concomitant with attachment/entry into a neighbor cell [46]. In HIV-1 and other retroviruses, viral glycoproteins located in cell surface stimulate the establishment of filopodes, which are used as bridges for cell-to-cell spread [47]. Several lines of evidence indicate that cell-to-cell virion passage through virological synapses is a major route of intra-host viral dissemination for HIV-1, human T cell leukaemia virus 1, and hepatitis C virus [37-53]. HTLV-1 uses virus-containing biofilm to spread virions between neighbor cells [50]. In vaccinia virus and other poxviruses, newly assembled viral particles remain associated to the surface of the infected cell, where they induce actin polymerization and the production of cellular projections that enhance viral transmission to neighboring cells [54]. Multiple genomes initiate a new cell infection [55]. Viral population diversity plays a role in its adapting to new host environment [56].

The concentrations of other substances used by virus influences viral infection and reproduction speeds. Envelope is involved in critical aspects of the viral reproduction cycle [57]. This role of this protein implies that restriction of certain amino acids in a certain time window may slow down viral reproduction and mechanical measures may disrupt the formation of the envelope.

The coronavirus has high genomes diversity. This property in combination of collective infection implies that a high concentration of viruses is a required condition for increasing viral reproduction spreed.

Health condition of the lungs affects virus infection and spread [61], and can be explored to slow down the viral reproduction speed. The lung health depends on nutritional balance. In any time, healthy pulmonary circulation is required to maintain nutritional balances and the waste removal balance. If those balances are lost, the lungs are slowly damaged by lack of essential nutrition and accumulated toxic substances. Replication of coronavirus induces the Unfolded Protein Response and other cellular stress responses in infected cells, triggering innate immunity and antiviral signaling pathways. The translational control is targeted and subverted by various coronaviruses at different levels via different mechanisms [62]. It can be assumed that lung health affects the host ability to resist virus infection. 
Coronavirus spike protein seems essential to infectivity and viral entry [5860]. Increased virulence was associated with the efficiency of interaction of the spike protein and the viral receptor on the rat cells, increased age of the rodent and mutations in the viral genome. Viruses get protein from the host cell membranes to form the virus envelope. The protein shell plays many roles in viral infection, including virus attachment to cells, entry into cells, release of the capsid contents into the cells, and packaging of newly formed viral particles. A large number of factors might be used to hinder this protein, thereby reducing the area A in Figure 1.

Adaptive immune response speeds can be influenced by using a large number of factors. Immunocompetence of a person depends on many factors such as age, pregnancy, and nutrient intake of various types (63-74) and potentially mechanic property [75]. This is implied by the fact that cell division is sensitive to mechanical activities, and mechanical activities may disrupt RNA replication.

Both malnutrition and obesity adversely affect the ability of a host to mount robust innate and adaptive immune responses to viral infections (76-84). Low zinc level, commonly reported in the elderly, impairs immune function, decreases resistance to pathogens, and is associated not only with increased incidence and duration of pneumonia, increased use and duration of antimicrobial treatment, but also with increased overall mortality in the elderly [85]. Those factors can be used to reduce areas A and B as well as the magnitude of curve D and avoid the D2 curve appearance in Figure 1.

The virus can cause various levels of stress [86]. Stressful events can influence the functioning of the immune system [87, 88, 89]. Several systematic reviews and meta-analyses have shown that particularly chronic stress suppresses protective immune responses and promotes pathological immune responses, including inflammatory responses [90-97]. These immune alterations can be expressed as slower wound healing [91, 92], impaired responses to vaccines [90], and progression of infectious and immune-mediated diseases [90, $98,99,100]$. Moreover, host immunocompetence influence viral virulence during in vivo passage; and stress-reducing interventions can improve immune responses [101], thus reducing area B and avoiding curve D2 appearance.

In the Saudi Arabia MERS-CoV outbreak, the chance of survivals among confirmed cases were associated with younger age, breathing ambient air, not being transferred to the intensive care unit and not receiving renal replacement therapy [101]. The observed age-related death rate can be explained by weakened immune system and poor blood circulation which is resulted from less physical activity common among the elderly. Another big factor is that elderly people have reduced organ functional capacities [102-104].

Lung disease severity can be altered by herbs. Glycyrrhizin, a compound found in liquorice roots, was reported to have a good in-vitro activity against SARS-CoV [105]. Health behaviors can influence disease severity [106]. 


\section{Summaries of Measures for Reducing Damages To Lungs}

To reduce areas A and B and prevent D2 curve appearance, strategies further include improving micro circulation in the lung tissue, improving the renal function, avoiding and reducing other sources of inflammation, reducing physical activities, avoiding using allergic foods, improving the vascular system, and changing immune response characteristics. Even based current knowledge, hundreds of factors can be used to alter disease outcomes. We summarize key measures in the following table.

Table 1 Treatment measures for reducing damages to lungs.

\begin{tabular}{|c|c|c|c|}
\hline Measures & \begin{tabular}{|l} 
Application \\
Details
\end{tabular} & Known Mechanisms & $\begin{array}{l}\text { Our Reasons (A, B and D2 } \\
\text { and D1) }\end{array}$ \\
\hline $\begin{array}{l}\text { Drink a lot } \\
\text { water }\end{array}$ & $\begin{array}{l}\text { Drink two or } \\
\text { three times of } \\
\text { water one } \\
\text { normally } \\
\text { drinks }\end{array}$ & $\begin{array}{l}\text { Implied by MOI, } \\
\text { corrective infection, } \\
\text { and waste removal }\end{array}$ & $\begin{array}{l}\text { The vital role of viral } \\
\text { concentration, and waste } \\
\text { removal (A and } B, D 2 \rightarrow D 1)\end{array}$ \\
\hline $\begin{array}{l}\text { Take } \\
\text { reasonabl } \\
\text { e amounts } \\
\text { of salt }\end{array}$ & \begin{tabular}{|l|} 
Take moderate \\
amount of salt \\
to maintain \\
electrolyte \\
balance
\end{tabular} & $\begin{array}{l}\text { Not recommended, } \\
\text { but some doctors } \\
\text { advice it }\end{array}$ & $\begin{array}{l}\text { Salt is essential for } \\
\text { maintaining the CNS } \\
\text { function; and an increased } \\
\text { ionic strength in the body } \\
\text { fluid can help remove the } \\
\text { viral, cellular waste, and } \\
\text { metabolic wastes more easily } \\
(\mathrm{B}, \mathrm{D} 2 \rightarrow \mathrm{D} 1)\end{array}$ \\
\hline $\begin{array}{l}\text { Keep } \\
\text { emotional } \\
\text { calm }\end{array}$ & $\begin{array}{l}\text { Counseling } \\
\text { and exercises } \\
\text { can improve } \\
\text { emotional } \\
\text { state }\end{array}$ & $\begin{array}{l}\text { Emotional distress } \\
\text { and chronic stress } \\
\text { suppress immunity \& } \\
\text { stricture blood } \\
\text { vessels }\end{array}$ & $\begin{array}{l}\text { Severe emotional distress can } \\
\text { divert the CNS resources and } \\
\text { make less resources for } \\
\text { regulating the immune } \\
\text { system }(A, B, D 2 \rightarrow D 1)\end{array}$ \\
\hline $\begin{array}{l}\text { Vitamins } \\
\text { C, A, K, B, } \\
\text { etc. and } \\
\text { other } \\
\text { nutrients }\end{array}$ & $\begin{array}{l}\text { Use vitamins, } \\
\text { etc. to improve } \\
\text { immune } \\
\text { system, \& host } \\
\text { defense. }\end{array}$ & $\begin{array}{l}\text { There are a large } \\
\text { number of studies on } \\
\text { vitamins, etc; } \\
\text { however long-term } \\
\text { over-use is not good }\end{array}$ & $\begin{array}{l}\text { We favor using fresh and } \\
\text { pollutant-low vegetables and } \\
\text { fruits to void catalysts, } \\
\text { pollutants, and over- } \\
\text { consumption imbalance (A, } \\
\text { D2 } \rightarrow \text { D1). }\end{array}$ \\
\hline $\begin{array}{l}\text { Do deep } \\
\text { breathing } \\
\text { exercise }\end{array}$ & $\begin{array}{l}\text { When the } \\
\text { lungs are } \\
\text { capable, do } \\
\text { deep breathing } \\
\text { exercise for 2- } \\
8 \text { hrs a day. }\end{array}$ & $\begin{array}{l}\text { Medical evidence } \\
\text { starts emerging. It } \\
\text { can improve oxygen } \\
\text { in blood by up to 30\% } \\
\text {; many studies were } \\
\text { done in China in } \\
\text { 1950s. }\end{array}$ & $\begin{array}{l}\text { The exercise improves energy } \\
\text { metabolism, increases lung } \\
\text { blood micro-circulation, } \\
\text { facilitates waste removal, and } \\
\text { increased mechanical } \\
\text { vibration in lungs promote } \\
\text { waste removal (A, B, D2 } \rightarrow \text { D1). }\end{array}$ \\
\hline
\end{tabular}




\begin{tabular}{|c|c|c|c|}
\hline \begin{tabular}{|l|} 
Improve \\
air quality
\end{tabular} & $\begin{array}{l}\text { Improve air } \\
\text { quality or } \\
\text { improve } \\
\text { ventilation }\end{array}$ & $\begin{array}{l}\text { Increase oxygen by } \\
2 \% \text { to } 5 \% \text { is } \\
\text { important; and avoid } \\
\text { secondary infections }\end{array}$ & $\begin{array}{l}\text { Disrupt potential interactions } \\
\text { between different viruses } \\
\text { from air; slow done re- } \\
\text { infection by patient's own } \\
\text { virus; prevent future infection } \\
\text { by independent viruses }\end{array}$ \\
\hline \begin{tabular}{|l} 
Utter \\
sounds
\end{tabular} & $\begin{array}{l}\text { Based on six } \\
\text { sounds deep } \\
\text { breathing } \\
\text { exercise (used } \\
\text { for more than } \\
1000 \text { years) }\end{array}$ & $\begin{array}{l}\text { Collective infection, } \\
\text { and formation of } \\
\text { protein envelope, etc } \\
\text { requires a calm } \\
\text { environment; sound- } \\
\text { inducing vibrations } \\
\text { disrupt required } \\
\text { condition }\end{array}$ & $\begin{array}{l}\text { It disrupts a calm } \\
\text { environment, improves blood } \\
\text { circulation, promotes waste } \\
\text { removal, stimulates nerve } \\
\text { signal transmission, etc. Take } \\
\text { time to get a result (B, } \\
\text { D2 } \rightarrow \text { D1) }\end{array}$ \\
\hline Relaxation & $\begin{array}{l}\text { Try to relax in } \\
\text { the whole } \\
\text { body, } \\
\text { especially } \\
\text { lungs. }\end{array}$ & $\begin{array}{l}\text { Many studies found } \\
\text { that relaxation can } \\
\text { help health by } \\
\text { affecting blood } \\
\text { vessels; improve } \\
\text { immune cell } \\
\text { migration efficiency }\end{array}$ & $\begin{array}{l}\text { Relaxation can cause a few } \\
\text { percents of expansion of } \\
\text { blood vessels, reduce blood } \\
\text { flow resistance, and improves } \\
\text { blood circulation (A, D2 } \rightarrow \text { D1) }\end{array}$ \\
\hline \begin{tabular}{|l|} 
Avoid \\
doing \\
exercise \\
when lung \\
function is \\
depressed
\end{tabular} & $\begin{array}{l}\text { When the } \\
\text { lungs are } \\
\text { under distress } \\
\text { and experience } \\
\text { shortness of } \\
\text { breath, avoid } \\
\text { physical } \\
\text { activities } \\
\end{array}$ & $\begin{array}{l}\text { This is used in } \\
\text { medicine for its } \\
\text { entire history. }\end{array}$ & $\begin{array}{l}\text { When the lung usable } \\
\text { function has reached to a } \\
\text { disability level, any physical } \\
\text { exercise will produce more } \\
\text { metabolic wastes, and further } \\
\text { degrade the waste removal } \\
\text { balance (D2 } \rightarrow \mathrm{D} 1 \text { ) }\end{array}$ \\
\hline \begin{tabular}{|l|} 
Use warn \\
foods such \\
as ginger, \\
date, \\
citrus, etc. \\
\end{tabular} & $\begin{array}{l}\text { A big class of } \\
\text { foods can } \\
\text { make people } \\
\text { warn. }\end{array}$ & $\begin{array}{l}\text { (Some } \\
\text { emers }\end{array}$ & $\begin{array}{l}\text { Warn foods can improve } \\
\text { blood circulation, improve } \\
\text { immune cell migration and } \\
\text { waste removals (A and B, } \\
\text { D2 } \rightarrow \text { D1) }\end{array}$ \\
\hline $\begin{array}{l}\text { Ginseng } \\
\text { and } \\
\text { similar } \\
\text { things }\end{array}$ & $\begin{array}{l}\text { Ginseng is } \\
\text { commonly } \\
\text { used to extend } \\
\text { life in critical } \\
\text { time }\end{array}$ & $\begin{array}{l}\text { The effect is similar } \\
\text { to steroids which can } \\
\text { improve energy } \\
\text { metabolism (for short } \\
\text { term use) }\end{array}$ & $\begin{array}{l}\text { In certain cases, it can } \\
\text { improve energy metabolism, } \\
\text { and improve the usable } \\
\text { capacity of lungs, kidneys and } \\
\text { heart. However, avoid long- } \\
\text { term use (B, D2 } \rightarrow \text { D1) }\end{array}$ \\
\hline $\begin{array}{l}\text { Steroids } \\
\text { and } \\
\text { oxygen }\end{array}$ & $\begin{array}{l}\text { Steroids and } \\
\text { oxygen are } \\
\text { routinely used }\end{array}$ & $\begin{array}{l}\text { Improve energy } \\
\text { metabolism and } \\
\text { improve lung micro- }\end{array}$ & $\begin{array}{l}\text { It is important to prevent or } \\
\text { mitigate damages to lung } \\
\text { tissues for patients who have }\end{array}$ \\
\hline
\end{tabular}




\begin{tabular}{|c|c|c|c|}
\hline & $\begin{array}{l}\text { in treating } \\
\text { lung infections }\end{array}$ & circulation & $\begin{array}{l}\text { experienced shortness of } \\
\text { breath }(B, D 2 \rightarrow D 1) \text {. Overuse } \\
\text { damages bone. }\end{array}$ \\
\hline $\begin{array}{l}\text { Anti- } \\
\text { inflammati } \\
\text { on foods } \\
\text { and herbs }\end{array}$ & $\begin{array}{l}\text { A large } \\
\text { number of } \\
\text { foods and } \\
\text { herbs can } \\
\text { reduce } \\
\text { inflammation }\end{array}$ & $\begin{array}{l}\text { Inflammation is the } \\
\text { cause of all chronic } \\
\text { diseases and a culprit } \\
\text { of bad health }\end{array}$ & $\begin{array}{l}\text { Although medicine separates } \\
\text { infection from inflammation, } \\
\text { they play a similar role in the } \\
\text { organ usable function and } \\
\text { waste removal }(A, B, D 2 \rightarrow D 1)\end{array}$ \\
\hline $\begin{array}{l}\text { Avoid } \\
\text { other- } \\
\text { infections }\end{array}$ & $\begin{array}{l}\text { Avoid other } \\
\text { viral infections } \\
\text { before this } \\
\text { infection is } \\
\text { resolved }\end{array}$ & $\begin{array}{l}\text { Collective infection } \\
\text { theory; } \\
\text { burden on immune } \\
\text { system; and B cells } \\
\text { exclusivity, etc. }\end{array}$ & $\begin{array}{l}\text { Other infections can bring } \\
\text { down the usable organ } \\
\text { function; and other } \\
\text { inflammation makes lung } \\
\text { micro-circulation worse (B, } \\
\text { D2 } \rightarrow \text { D1). }\end{array}$ \\
\hline $\begin{array}{l}\text { Eat anti- } \\
\text { virus } \\
\text { foods such } \\
\text { as garlic, } \\
\text { onion, etc. }\end{array}$ & $\begin{array}{l}\text { Garlic, onion, } \\
\text { shallot, leek, } \\
\text { chive are used } \\
\text { to fight viruses } \\
\text { and improve } \\
\text { the heart. }\end{array}$ & $\begin{array}{l}\text { A large number of } \\
\text { studies show they } \\
\text { have many roles but } \\
\text { lack direct evidence } \\
\text { on cold-related } \\
\text { viruses (note such } \\
\text { study limitations) }\end{array}$ & $\begin{array}{l}\text { We accept well known } \\
\text { working mechanisms, but } \\
\text { reject the conflicting or } \\
\text { inconclusive findings from } \\
\text { population based studies (A, } \\
\text { B, D2 } \rightarrow \text { D1) }\end{array}$ \\
\hline $\begin{array}{l}\text { Physical } \\
\text { exercise } \\
\text { before } \\
\text { infection }\end{array}$ & $\begin{array}{l}\text { Do regular } \\
\text { exercise one } \\
\text { hour a day }\end{array}$ & $\begin{array}{l}\text { Improve the vascular } \\
\text { system and micro } \\
\text { circulation in all } \\
\text { major organs. }\end{array}$ & $\begin{array}{l}\text { Exercise increases blood flow } \\
\text { capacity by } 2 \mathrm{X} \text { to } 3 \mathrm{X} \text { (one } \\
\text { feels NO shortness of breath } \\
\text { when running at typical } \\
\text { marathon speed) (A, B). It } \\
\text { can dramatically improve } \\
\text { ability to fight COVID-19. }\end{array}$ \\
\hline $\begin{array}{l}\text { Reduce } \\
\text { heavy } \\
\text { metals \& } \\
\text { pollutants } \\
\text { levels in } \\
\text { the body }\end{array}$ & $\begin{array}{l}\text { Many heavy } \\
\text { metals and } \\
\text { pollutants can } \\
\text { suppress } \\
\text { immunity }\end{array}$ & $\begin{array}{l}\text { A large of studies } \\
\text { produced direct and } \\
\text { indirect evidence of } \\
\text { their adverse effects } \\
\text { on immunity }\end{array}$ & $\begin{array}{l}\text { Disease severity is due to a } \\
\text { delayed immune response. If } \\
\text { the delay is reduced from } 10 \\
\text { days to } 2 \text { days, an infection is } \\
\text { very mild. Reducing heavy } \\
\text { metals is one important } \\
\text { preventive measure. }\end{array}$ \\
\hline $\begin{array}{l}\text { Lifestyle } \\
\text { manner } \\
\text { promotes } \\
\text { viral } \\
\text { spread }\end{array}$ & $\begin{array}{l}\text { Viral spread } \\
\text { from one to } \\
\text { millions of } \\
\text { alveoli cannot } \\
\text { be explained } \\
\text { by cell-cell } \\
\text { transmission }\end{array}$ & $\begin{array}{l}\text { Binary approach uses } \\
\text { an oversimplified } \\
\text { approach and has not } \\
\text { studied it }\end{array}$ & $\begin{array}{l}\text { Collective infection findings, } \\
\text { human flu studies, and animal } \\
\text { flu studies, etc. support our } \\
\text { view: the virus and other } \\
\text { viruses are spread by } \\
\text { breathing process. Studies } \\
\text { should be done to understand }\end{array}$ \\
\hline
\end{tabular}


how patient lifestyle and manners affect reinfection

Those measures can be used to make two areas A and B (Figure 1) smaller. If those measures are used in time, in good combination, it is possible to prevent or reduce damages to lung tissues substantially or completely.

Per our personal research experience, we found that salt raises ionic strength and reduces the viscosity of biological materials. Protein sols can be dissolved when salt is added. Thus, moderate salt is used to improve waste removal balance (not killing viruses). For patients who are unable to cough and have no lung discharges, waste removal should be regarded as the first priority. Any additional measures such as continuous deep-breathing, uttering sounds, maintaining warn temperature, eating hot foods, generate mechanical vibrations, etc. may be considered. Bringing the body into a relaxing state can improve blood flow significantly through enlarging vessel diameters.

\section{E. Multiple Factors Health Optimization Is Superior to Reductionist Approach}

Now we prove that multiple factors treatment is potentially the most powerful cure for COVID-19 disease. We have shown that a large number of factors, all found from published research articles, can be used to slow down viral infection, reproduction and spreading, speed up immune responses, and promote virus-waste distribution in the body. Medical basic research has long ago solved this problem. As for other diseases, more than $99 \%$ of medical findings are not used in treatment practice. The reason is that the legal framework recognize only treatment protocols developed by using randomized controlled trials (RCTs). We prove that that RCT is an incorrect method.

\section{Proof by mathematical model}

We have proved that randomized controlled trials are not a suitable method for studying week and slow-delivering effect as long as one interfering factor of a similar effect exists in the human body [107]. In the cited study, we found that when $\mathrm{N}$ factors can be used, each having the same amount of benefit, the real total benefit of $\mathrm{N}$ factors is more than what would be detected for one single factor in a controlled trial by about $(1 / \mathrm{g}) \mathrm{k}$ times; and statistics for conducting a hypothesis is off by $(1 / \mathrm{g}) \mathrm{k} \sqrt{\mathrm{k}}$ times, making findings from randomized controlled trails meaningless. If a person uses one hundred of factors to treat a disease, the true benefits would be about $100 * 100=10000$ times stronger than nominal values determined by such a trial using only one factor. Statistical analysis is completely meaningless.

The flaw in RCTs can be seen by common sense. A treatment, which gives $50 \%$ negative responses, $40 \%$ positive responses, and $10 \%$ neutral responses, is a good treatment for those $40 \%$ patients even if the averaged treatment for the 
treatment group has negative benefits. Health conditions, treatment responses and death risks found from other people have nothing to do with those of a particular person. We should easily see that health condition, disease condition or treatment response of any person in the U.S. have nothing to do with those of people in China, Europe or Russian.

2. Proof by graphic representation

The flaw of using randomized controlled trials is shown in Figure 2 below.
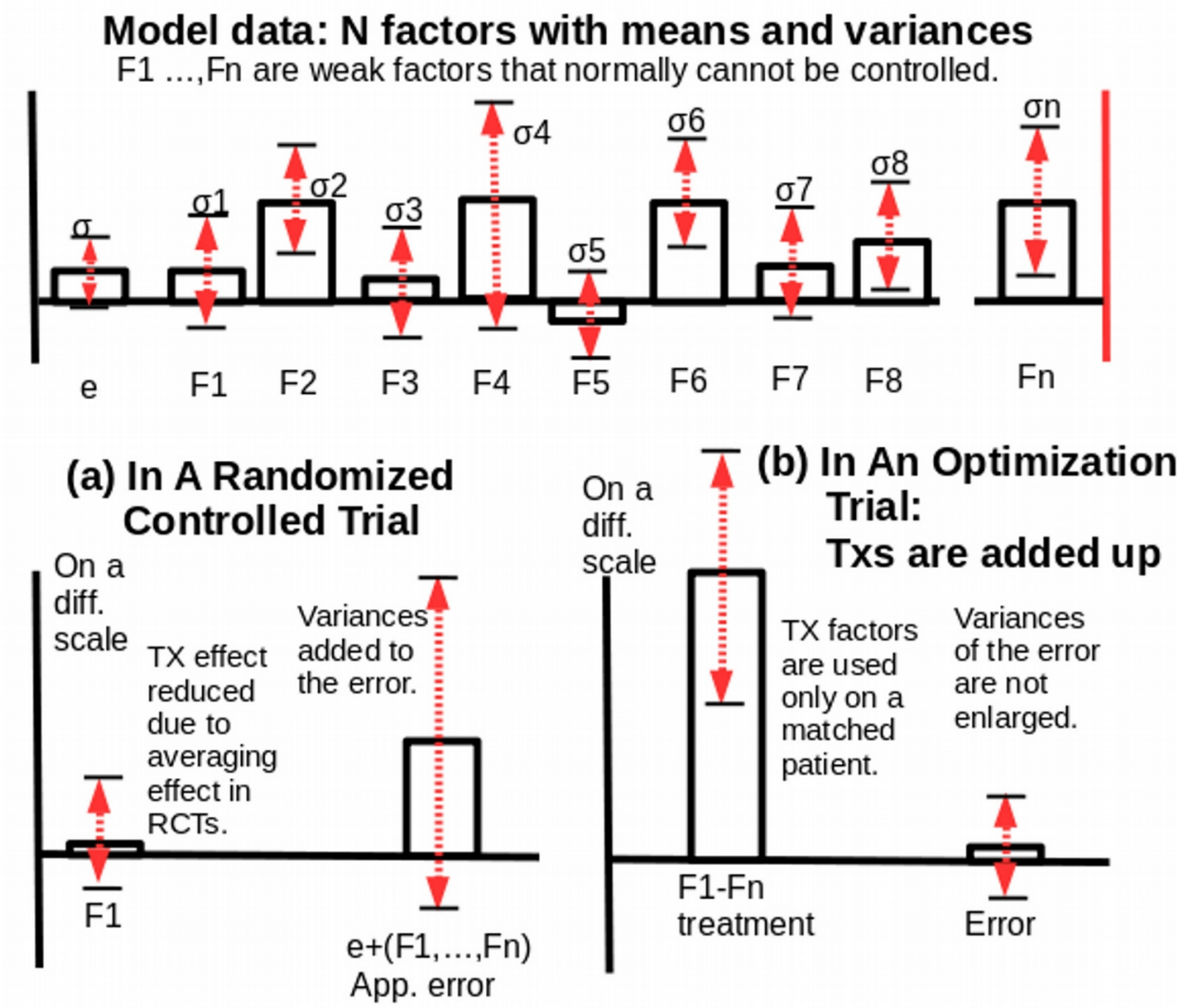

Figure 2, a health condition depends on $\mathrm{N}$ factors (F1 to Fn) with an error term. In a randomized controlled trial shown in insert (a), one big flaw is indiscriminate application of one factor to all people in the trial. This results in canceling-out of positive benefits on some people and negative effects on other people, and adds all of the uncontrolled factors into the error term to inflate the error term size. There is no way to find F1 as compared with the big apparent error. In a multiple factors optimization trial (HOT) shown in insert (b), F1-Fn factors are used simultaneously while the error term is much smaller.

Figure 2 shows that HOT is much more powerful than the reductionist approach. If hundreds of factors are used, Treatments in HOT could be 10000 times of what is achieved in RCTs (assuming each factors have same benefits and 
people respond to each factor in 1/100). This poor responsive rate is why chronic diseases are known as incurable. The misuse of RCT is the main reason that medicine does great basic research but could not utilize discoveries in curing diseases.

\section{Confusion caused by population-based trials}

Some studies reached conflicting and negative conclusions. Conclusions are normally based on randomized controlled trials and statistical analysis. In each of such studies, one treatment or one measure is studied without regarding differences in application timing, patient conditions, and all other problems. It is like mixing many things in an attempt to see an end result. Failure to see benefits is natural.

A person dies when the usable organ function reaches a threshold of death, which is independent of organ functional reserve. Based on the vascular capacity, the usable lung capacity is reduced from the highest value (100\%) to about $20 \%$ as the death threshold. We found that a large number of factors affect the usable capacity in an additive manner; and that each of the factors can raise usable lung function [107]. Lung damages are NOT caused in a binary manner but quantitatively. Tens to hundreds of things may be used to preserve some of the surplus $80 \%$ heart function. Young men can tolerate drugs well so drugs might be safe for them. For old people whose basic lung function has reached the disability level, any additional damage or stress to the drugs can result in adverse result [108]. Old people should not be treated like young people.

Emotional health or absence of emotional stress is vitally important in controlling the virus. Findings from studies on improving immune responses are weak. However, emotion is a kind of things that cannot be studied by randomized controlled trails. When many interfering factors exist, the errors used in statistical analysis have been raised by two to several folds. Moreover, the effectiveness of measures depends on individual persons. Emotional health and interventions for emotional health cannot be judged by population outcomes.

Air quality is a vital factor in fighting lung infections, but is not used in treating patients. Air in a poorly ventilated room contains $1 \%$ to $5 \%$ lower oxygen level than fresh air from nature. Air containing less oxygen but more bacteria, viruses and harmful substances are bad to patients. Simultaneous infection by other viruses and bacteria burden the immune system. If a person has five types of viruses to fight, the immune system has to divide their "troops", the immune cells, to fight five battles against all viruses. When fresh air is unavailable, the healthcare industry should remove from air viral particles and restore oxygen level to the natural level.

In the clinical setting, the ultimate strategy is to save lung tissue from direct viral damages and "collateral" damages. When shortness of breath is noted, a presumption is that blood circulation in the lungs is severely impaired and tissue damages are in the process. Using corticosteroids and improving 
oxygen can prevent further damages [109]. However, the drugs cause severe bone damages to survivals [110].

\section{Evaluate negative findings in research articles}

It is often said that only FDA-approved drugs or protocols can cure diseases. That claim is proved to be wrong. FDA proves medical treatments by reductionist approach, its potential benefit is severely limited. We have proved by mathematical models, visual justification, and common sense reasoning that multiple factors health optimization is superior.

Some studies may produce evidence contrary to our recommended measures for controlling cold or this virus. The obvious reason is the inherent bias we have discussed above. We can prove their beneficial effects by studying their working mechanisms and interactions with others.

Another problem is the limitation of reductionist approach. When a treatment is found to be bad to health from one mechanism, it may be still good to health from other mechanisms unless the treatment influences health by only one mechanism. Glucosinolates found in garlic (as well as cruciferous vegetables) have an antibiotic-like effect and help ward off bacterial, viral, and fungal infection in the intestines and other parts of the body. This compound can fight herpes simplex types 1 and 2, human rhinovirus type 2, parainfluenza virus type 3, vaccinia virus, and vesicular stomatitis virus. There is NO evidence that garlic can fight COVID-19. However, garlic is also known to have numerous indirect effects: it has antioxidant activity, lipid (cholesterol and triglyceride) lowering, platelet aggregation inhibition, enhancement of fibrinolytic activity, prolongation of bleeding and clotting time, and prevention of LDL oxidation. It also possesses anti-inflammatory properties, hypoglycemic actions, digestive effects and cleansing actions. As a whole, garlic can improve micro circulation in the lungs, improve the immune function, and promotes holistic health. Since garlic is a food and does not pose risk, one can use it unless there is a specific reason for not using it. Thus, negative findings for a measure from controlled trials do not disprove its benefits on some patients.

5. Evaluate additive benefits from individual factors

Each of the listed measures could make a difference if it is correctly used on a right person. Increasing water intake by one time (1X) may bring out wastes by more than a few percents; using salt in reasonable amounts may help remove more viral and cellular debris in a given time. Emotional factor can make differences in some patients. Vitamins and essential nutrients for the immune system may shorten the phase lag by one to two days; deep breathing can improve energy metabolism by as much as 30\%; and avoiding exercise when lungs are distressed may save MET values by up to 70\%; relaxation exercise can reduce blood pressure by more than $10 \%$; and avoiding a secondary infection can reduce burden on the immune system, reduce viral burden, and help maintain the waste removal balance in the lungs. Warn foods such as ginger, date, citrus, 
etc. are known to improve blood circulation and energy production; antiinflammatory and antivirus foods such as garlic, onion, shallot, leek, and chive are also good, regardless of conclusions in some studies.

If they are used in combination, their benefits are added up. Most of the listed measures can be used with or without medical treatments.

Lungs, heart and kidneys work together. The degraded blood circulation in the lung tissue and increased amounts of wastes make the lungs progressively worse. Even a small deficiency in the early stage can progressively degrade the performance of the lungs and bring down heart and kidneys. However, lungs suffer the most serious damages. Oxygen, steroids and certain herbs may effectively mitigate lung damages by improving micro-circulation. We believe that the most promising fast-acting cures are herbal formulations. Good herbal formulations can be used to improve their functions at same time. Herbs may be used to reduce areas A and B substantially and dramatically improve waste removal capacities. Some formulations have appeared at the time of wring this article, we will include them in a late version or our data files. Effective measures should be used as early as possible.

Keeping the body warn and avoiding exposure to low temperature are vitally important $[111,112]$. Temperature affects blood circulation, immune cell migration and waste removal. One important reason is that people tend to stricture blood vessels at low temperatures [111]. Avoiding other antigens is important because each B cell can produce anybodies that bind to only one type of antigens. If the person suffers multiple unrelated infections, the immune system is over burdened.

When the viral reproduction curve and the immune response curve have a few days phase lag, it is possible to starve some viruses in the early stage by limiting materials that are essential to viral reproduction and then boost nutrition to promote the immune system after the immune response starts. The old thinking to get better nutrition may be not the best strategy for some patients. In the early stage, resource limitation may slow down early viral development. However, one difficulty is to correctly find the infection time. If one knows that he has been exposed to the virus, it may be worthwhile to impose specific nutritional restriction for a few days and then improve nutritional supply for promoting the immune system.

We noted that the total time for recovering from a cold or flu can be reduced to hours or less than a day as compared with several weeks. Similarly, we noted from personal experience that severe seasonal allergic reactions to pollen can be achieved by adjusting lifestyle. Those changes can be explained by the waste removal balance. Antigens enter the body in varying speeds. If the body is unable to remove antigens and their metabolic products from blood circulation, the body must remove them by discharging fluid from running nose, sneezing, and coughing. Those symptoms are necessary to restore the waste- 
removal balance. The imbalance can be restored in the alternative by improving micro-circulation efficiency.

When medical treatments are unavailable, do everything possible to reduce A and B areas and improve the waste removal. Upon a suspected infection or the appearance of the earliest signs, keep body warn and avoid exposure to low temperature, drink more water containing moderate amount of salt, do deep breathing exercises continuously with focus being on the lungs, utter sound when doing deep breath (using the Shi sound or all six sounds for the entire exercise), consume hot foods, anti-inflammation foods (and herbs if you can find); do not use any drugs to stop coughs in the late stage, do not try to avoid coughing (but avoid coughing at other people), and avoid other infections in the narrow time window. Depending on how much effort is made, the person may be able to reduce A and B from a few percents to completely. If large scale lung tissue necrosis is avoided, most lung functional reserve may be saved or recovered.

Preventive behavioral responses can affect outcomes of population. Due to the differences in death risks, if one must be infected by the virus, then infection by a non-lung body parts may change disease outcomes. This should be studied before it can be used in real persons. When vaccine is unavailable, it can be lifesaving measure if it is used correctly together with other protective measures.

Physical activities, environment pollutants, body physical condition, mechanical state, emotional state, etc. can alter disease outcomes because they affect areas A and B, and the waste removal balance. Any of the properties that have been known [113-119] or will be discovered in the future may be employed to alter the phase lag and waste removal efficiency in the lungs. We hope that hundreds to thousands of more factors can be used in the future in this treatment framework. The final goal is turning each disease into a mild flu.

\section{LIMITATIONS OF THE STUDY}

The analysis has some conflicts with epidemiological concepts such as exposure, infection, incubation time, latent time, etc. It is obvious that virus exposure for REAL humans exist from before a supposed exposure to after complete recovery of the disease; and lungs (with 600 million alveoli) may be infected at multiple points in different times, repeatedly re-infected by inhaling patient own viruses, successively infected by external viruses, and even coinfected by other viruses. COVID-19 may enter the body here and there before the medically recognized "exposure" or infection, during treatment, during recovery and even in a healthy state. Those terms, which are used in an oversimplified binary system, do not reflect reality (unless human beings were controlled like laboratory animals). Similarly, the value of those terms cannot be modeled by using one single value. Our analysis goes beyond those limitations. 
This study was performed by applying data from related viruses and diseases. Thus, absolute numbers found in all computation examples tell only disease trends which are important in finding optimization direction. No data can be directly used on persons. In personalized medicine, each treatment is tailored to a specific person and his disease. The treatment strategies are useful to all viruses that can infect lungs because most of the measures do not depend on molecular specificity. They are expected to be useful to SARS, coronavirus (COVID-19, influenza, etc. Some of them can be used to ward off common cold or bacterial infections.

\section{CHANGE HISTORY}

The first draft was a working paper intended as a life-saving aid for people who do not respond to drugs or are unable to receive medical services. Despite a nature of draft, key points for controlling lung damages are beyond challenge because they are backed up by a large number of studies we know. Most of suggested non-medical measures such as deep breathing exercises, sound uttering, relaxation, emotional management, etc. were known and used for thousands of years in multiple cultures, and have been used by one of the authors for stop or mitigate influenza for years.

In this first revised version, we provide stronger proof that multiple factors health optimization method is superior to reductionist approach. This is the core notion in Chinese Medicine and other ancient health arts. This article will be periodically updated to correct remaining errors and omissions.

\section{FUNDING STATEMENT}

The author(s) declared that no grants were involved in supporting this work.

\section{ADDITIONAL INFORMATION}

Additional information is provided in a supplemental document and some information may be stored in igoosa.com online database.

This article may be used by any person for personal use as fair use; any use for research and academic exchanges is permitted by default; if anyone wants to 
translate the article into other languages, please let us know, we will grant the permission.

\section{REFERENCES}

1. World Health Organization WHO. Summary of probable SARS cases with onset of illness from 1 November 2002 to 31 July 2003 2003. Available from: http://www.who.int/csr/sars/country/table2004_04_21/en/index.html.

2. World Health Organization WHO. WHO MERS-CoV Global Summary and Assessment of Risk, August 2018 (WHO/MERS/RA/August18) 2018. Available from: http://www.who.int/csr/disease/coronavirus infections/risk-assessmentaugust-2018.pdf?ua=1.

3. Parvez, M.K.; Parveen, S. Evolution and Emergence of Pathogenic Viruses: Past, Present, and Future. Intervirology 2017, 60,1-7.

4. Burkle, F.M. Jr. Global Health Security Demands a Strong International Health Regulations Treaty and Leadership From a Highly Resourced World Health Organization. Disaster Med. Public Health Prep. 2015, 9, 568-580.

5. Liu SL and Saif L. Emerging Viruses without Borders: The Wuhan Coronavirus. Viruses 2020, 12, 130; doi:10.3390/v12020130

6. Jian Zheng, Stanley Perlman Immune responses in influenza A virus and human coronavirus infections: An ongoing battle between the virus and host. CuCurr Opin Virol. 2018 Feb; 28: 43-52.

7. Domingo E., Holland J. J. (1997) RNA Virus Mutations and Fitness for Survival, Annual Review of Microbiology, 51: 151-78.

8. Abdul-Rasool S, Fielding BC. Understanding Human Coronavirus HcoVNL63. Open Virol J. 2010; 4: 76-84.

9. Strasfeld L, Chou S. Antiviral Drug Resistance: Mechanisms and Clinical Implications. Infect Dis Clin North Am. 2010 Jun; 24(2): 413-437.

10. Cowling BJ, Leung GM. Epidemiological research priorities for public health control of the ongoing global novel coronavirus (2019-nCoV) outbreak. Euro Surveill. 2020;25(6):pii=2000110. https://doi.org/10.2807/15607917.ES.2020.25.6.2000110

11. Guyton AC. The cough reflex, In Text of Medical Physiology ( $8^{\text {th }}$ Ed). W.B. Saunders Company. pg 411-412 (various page rages).

12. Samji T. Influenza A: Understanding the Viral Life Cycle. Yale Journal Of Biology And Medicine 82 2009; pp.153-159. 
13. Yoo J-K, Kim TS, Hufford MM, Braciale TJ. Viral infection of the lung: Host response and sequelae. J Allergy Clin Immunol. 2013 December; 132(6): doi:10.1016/j.jaci.2013.06.006.

14. Wang I-N. Lysis Timing and Bacteriophage Fitness. 2006 by the Genetics Society of America. DOI: 10.1534/genetics.105.045922.

15. Nutt, Stephen L.; Hodgkin, Philip D.; Tarlinton, David M.; Corcoran, Lynn M. The generation of antibody-secreting plasma cells. Nature Reviews Immunology. 2015;15 (3): 160-71. doi:10.1038/nri3795. PMID 25698678.

16. Park WB, Perera RA, Choe PG et al. Kinetics of serologic responses to MERS coronavirus infection in humans, South Korea. Emerg. Infect. Dis. 2015;21:2186-2189.

17. Virlogeux V., Fang V.J., Park M., Wu J.T., Cowling B.J. Comparison of incubation period distribution of human infections with MERS-CoV in South Korea and Saudi Arabia. Sci. Rep. 2016;6:35839.

18. Centers for Disease Control and Prevention CDC Laboratory Testing for Middle East Respiratory Syndrome Coronavirus (MERS-CoV) (accessed on 10 July 2019); Available online: https://www.cdc.gov/coronavirus/mers/lab/labtesting.html.

19. Lauer SA et al. The incubation period of coronavirus disease 2019 (COVID-19) from publicly reported confirmed cases: Estimation and application. Ann Intern Med 2020 Mar 10; [e-pub]. (https://doi.org/10.7326/M20-0504)

20. Murphy, Kenneth (2012). Janeway's Immunobiology (8th ed.). New York: Garland Science. ISBN 9780815342434.

21. Nutt, SL, Hodgkin PD, Tarlinton, DM; Corcoran, LM. The generation of antibody-secreting plasma cells. Nature Reviews Immunology. 2015,15 (3): 16071. doi:10.1038/nri3795.

22. MacLennan, ICM; Toellner, K-M; Cunningham, AF et al. Extrafollicular antibody responses. Immunological Reviews.2003,194:8-18.

23. Shlomchik, Mark J.; Weisel, Florian. Germinal center selection and the development of memory B and plasma cells. Immunological Reviews. 2012; 247 (1): 52-63.

24. Fung S, Liao Y, Liu DX. Regulation of Stress Responses and Translational Control by Coronavirus. Viruses. 2016 Jul; 8(7): 184.

25. Gu J. and Korteweg C. Pathology and Pathogenesis of Severe Acute Respiratory Syndrome. The American Journal of Pathology, Vol. 170, No. 4, April 2007.

26. Xu Zhe, Shi L, Wang Y. et al. Pathological findings of COVID-19 associated with acute respiratory distress syndrome. The Lancet Respiratory 
Medicine. February 18, 2020. DOI:https://doi.org/10.1016/S2213-2600(20)30076$\underline{\mathrm{X}}$

27. Huang C, Wang Y, Li X. et al. Clinical features of patients infected with 2019 novel coronavirus in Wuhan, China. Lancet 2020; 395: 497-506.

28. Chihanga T, Ruby HN, Ma Q, Bashir S, Devarajan P, Kennedy MA. NMRbased urine metabolic profiling and immunohistochemistry analysis of nephron changes in a mouse model of hypoxia-induced acute kidney injury. Am J Physiol Renal Physiol. 2018 Oct 1;315(4):F1159-F1173.

29. Ter Maaten JM, Damman K, Verhaar MC et al. Connecting heart failure with preserved ejection fraction and renal dysfunction: the role of endothelial dysfunction and inflammation. Eur J Heart Fail. 2016 Jun;18(6):588-98.

30. Visconti L, Santoro D, Cernaro V, Buemi M, Lacquaniti A. Kidney-lung connections in acute and chronic diseases: current perspectives. J Nephrol. 2016 Jun;29(3):341-348.

31. Domenech P, Perez T, Saldarini A, Uad P, Musso CG. Kidney-lung pathophysiological crosstalk: its characteristics and importance. Int Urol Nephrol. 2017 Jul;49(7):1211-1215.

32. Sanjuán R. Collective infectious units in viruses. Trends Microbiol. 2017 May; 25(5): 402-412.

33. Shirogane Y, Watanabe S, Yanagi Y. Cooperation between different variants: A unique potential for virus evolution. Virus Res. 2019 Apr 15;264:6873.

34. Leeks A, Segredo-Otero EA, Sanjuán R, West SA. Beneficial coinfection can promote within-host viral diversity. Virus Evol. 2018;4/2.

35. Vignuzzi M, Stone JK, Arnold JJ, et al. Quasispecies Diversity Determines Pathogenesis Through Cooperative Interactions in a Viral Population, Nature, 2006; 439:344-8.

36. Kuss SK, Etheredge C. A., Pfeiffer J. K. Multiple Host Barriers Restrict Poliovirus Trafficking in Mice, PLoS Pathogens, 2008; 4: e1000082.

37. Gutiérrez S, Michalakis Y, Blanc S. Virus Population Bottlenecks During Within-Host Progression and Host-To-Host Transmission, Current Opinion in Virology, 2012;2: 546-55.

38. Aronson JF, Herzog NK, Jerrells TR. Tumor Necrosis Factor and the Pathogenesis of Pichinde Virus Infection in Guinea Pigs, The American Journal of Tropical Medicine and Hygiene, 1995;52: 262-9.

39. Tiwari A., Patnayak D. P., Chander Y., et al. Permissibility of Different Cell Types for the Growth of Avian Metapneumovirus, Journal of Virological Methods, 2006;138: 80-4. 
40. Vassalli JD, et al. Direct cell-to-cell transmission of vesicular stomatitis virus. J Cell Sci. 1986; 85:125-131.

41. Sattentau QJ. The direct passage of animal viruses between cells. Curr Opin Virol. 2011; 1:396-402.

42. Zhong P, et al. Cell-to-cell transmission of viruses. Curr Opin Virol. 2013; 3:44-50.

43. Sherer NM, et al. Retroviruses can establish filopodial bridges for efficient cell-to-cell transmission. Nat Cell Biol. 2007; 9:310-315. 51.

44. Andino R, Domingo E. Viral quasispecies. Virology. 2015; 479-480C:46-

45. Ciota AT, et al. Cooperative interactions in the West Nile virus mutant swarm. BMC Evol Biol. 2012;12:58-12.

46. Vassalli JD, et al. Direct cell-to-cell transmission of vesicular stomatitis virus. J Cell Sci. 1986;85:125-131.

47. Álvarez RA, et al. Unique features of HIV-1 spread through T cell virological synapses. PloS Pathog. 2014;10:e1004513.

48. Agosto LM, et al. HIV cell-to-cell transmission: effects on pathogenesis and antiretroviral therapy. Trends Microbiol. 2015;23:289-295.

49. Komarova NL et al. Synaptic transmission and the susceptibility of HIV infection to anti-viral drugs. Sci Rep. 2013; 3:2103.

50. Gross C, Thoma-Kress AK. Molecular mechanisms of HTLV-1 cell-to-cell transmission. Viruses. 2016; 8:74.

51. Pais-Correia AM et al. Biofilm-like extracellular viral assemblies mediate HTLV-1 cell-to-cell transmission at virological synapses. Nat Med. 2010; 16:83-89.

52. Xiao $\mathrm{F}$ et al. Hepatitis $\mathrm{C}$ virus cell-cell transmission and resistance to direct-acting antiviral agents. PLoS Pathog. 2014; 10:e1004128.

53. Graw F et al. Quantification of hepatitis C virus cell-to-cell spread using a stochastic modeling approach. J Virol. 2015; 89:6551-6561.

54. Dodding MP, Way M. Nck- and N-WASP-dependent actin-based motility is conserved in divergent vertebrate poxviruses. Cell Host Microbe. 2009; 6:536550 .

55. Miyashita S, et al. Viruses roll the dice: the stochastic behavior of viral genome molecules accelerates viral adaptation at the cell and tissue levels. PLoS Biol. 2015; 13:e1002094. 
56. Borucki MK, Allen JE, Chen-Harris H, et al. The Role of Viral Population Diversity in Adaptation of Bovine Coronavirus to New Host Environments, PLoS One, 2013a; 8: e52752.

57. Schoeman D and Fielding BC. Coronavirus envelope protein: current knowledge. Virology Journal. 2019;16:69.

58. Edward B. Thorp, Joseph A. Boscarino, Hillary L. Logan, Jeffrey T. Goletz, Thomas M. Gallagher. Palmitoylations on Murine Coronavirus Spike Proteins Are Essential for Virion Assembly and Infectivity. J Virol. 2006 Feb; 80(3): 1280-1289.

59. Dawn K. Krueger, Sean M. Kelly, Daniel N. Lewicki, Rosanna Ruffolo, Thomas M. Gallagher. Variations in Disparate Regions of the Murine Coronavirus Spike Protein Impact the Initiation of Membrane Fusion. J Virol. 2001 Mar; 75(6): 2792-2802.

60. Thorp EB, Boscarino JA, Logan HL, Goletz JT, Gallagher TM. Palmitoylations on murine coronavirus spike proteins are essential for virion assembly and infectivity. J Virol. 2006 Feb;80(3):1280-9.

61. Nagata N, Iwata N, Hasegawa H, et al. Participation of both host and virus factors in induction of severe acute respiratory syndrome (SARS) in F344 rats infected with SARS coronavirus. Journal of Virology, 2007; 81:1848-57.

62. Muller WA. Transendothelial Migration: Unifying Principles from the Endothelial Perspective.Immunol Rev. 2016 September; 273(1): 61-75.

63. Levander OA. Nutrition and Newly Emerging Viral Diseases: An Overview, Journal of Nutrition, 1997;127: 948S-50S;

64. Beck MA, Williams-Toone D, Levander OA. Coxsackievirus B3-Resistant Mice Become Susceptible in Se/Vitamin E Deficiency, Free Radical Biology and Medicine, 2003;34:1263-70.

65. Beck MA. Selenium and Vitamin E Status: Impact on Viral Pathogenicity, Journal of Nutrition, 2007;137: 1338-40.

66. Beck MA, Handy J, Levander OA. Host Nutritional Status: The Neglected Virulence Factor, Trends in Microbiology, 2004;12:417-23

67. Beck MA, Levander OA, Handy J. Selenium Deficiency and Viral Infection, Jourrnal of Nutrition, 2003;133: 1463S-7S.

68. Beck MA, Nelson HK, Shi Q, et al. (2001) Selenium Deficiency Increases the Pathology of an Influenza Virus Infection, The FASEB Journal, 15: 1481-3.

69. Alice M, Tang ES, Semba RD. (2013) Nutrition and Infection, in: Kenrad E., Nelson C.M.W., editors. (eds.) Infectious Disease Epidemiology: Theory and Practice, 3rd edn. Burlington, MA: Jones \& Bartlett Learning. 
70. Chandra RK. Nutrition and The Immune System: An Introduction, American Journal of Clinical Nutrition, 1997;66: 460S-3S.

71. Keusch GT. The History of Nutrition: Malnutrition, Infection and Immunity, Journal of Nutrition,2003;133: 336S-40S.

72. Nelson HK, Shi Q, Van Dael P, et al. Host Nutritional Selenium Status as a Driving Force for Influenza Virus Mutations, The FASEB Journal, 2001; 15: 1846-8. 10.1096/fj. 01-0115fje.

73. Ritz BW, Gardner EM. Malnutrition and Energy Restriction Differentially Affect Viral Immunity, Journal of Nutrition, 2006;136:1141-4.

74. Schaible UE, Kaufmann SH. Malnutrition and Infection: Complex Mechanisms and Global Impacts, PLoS Medicine, 2007;4: e115.

75. Yeung PK, Wong JT. Inhibition of cell proliferation by mechanical agitati on involves transient cell cycle arrest at G1 phase in dinoflagellates. Protoplasma. 2003 Mar;220(3-4):173-8.

76. Kanneganti TD, Dixit VD. Immunological Complications of Obesity, Nature Immunology, 2012;13: 707-12.

77. Karlsson EA, Beck MA. Diet-Induced Obesity Impairs The T Cell Memory Response to Influenza Virus Infection, The FASEB Journal, 2009;23: 110-3.

78. Karlsson EA, Sheridan PA, Beck MA. Diet-Induced Obesity Impairs the T Cell Memory Response to Influenza Virus Infection, The Journal of Immunology, 2010;184:3127-33.

79. Mito N, Hosoda T, Kato C, et al. Change of Cytokine Balance in DietInduced Obese Mice, Metabolism, 2000;49:1295-300.

80. Monteiro R, Azevedo I. Chronic Inflammation in Obesity and the Metabolic Syndrome, Mediators of Inflammation, 2010, pii:289645.

81. Nieman DC, Henson DA, Nehlsen-Cannarella SL, et al. Influence of Obesity on Immune Function, Journal of the American Dietetic Association, 1999; 99: 294-9.

82. Kanneganti TD, Dixit VD. Immunological Complications of Obesity, Nat Immunol, 2012;13:707-12.

83. Smith AG, Sheridan PA, Harp JB, et al. Diet-Induced Obese Mice have Increased Mortality and Altered Immune Responses when Infected with Influenza Virus, Journal of Nutrition, 2007;37:1236-43.

84. Aroor A. R., DeMarco V. G. (2014) Oxidative Stress and Obesity: The Chicken or the Egg? Diabetes, 63:2216-8. 
85. Barnett JB, Hamer DH, Meydani SN. Zinc: a new risk factor for pneumonia in the elderly? Nutr Rev. 2010 Jan; 68(1): 30-37.

86. Hawryluck L, Gold WL, Robinson S, Pogorski S. Galea S, Styra R. SARS Control and Psychological Effects of Quarantine, Toronto, Canada. Emerg Infect Disv. 10(7); 2004 Jul;10(7),1206-12.

87. Steptoe A, Hamer M, Chida Y. The effects of acute psychological stress on circulating inflammatory factors in humans: a review and meta-analysis. Brain Behav Immun. 2007 Oct;21(7):901-12.

88. Segerstrom SC, Miller GE. Psychological stress and the human immune system: a meta-analytic study of 30 years of inquiry. Psychol Bull. 2004 Jul;130(4):601-30.

89. McCann SM. Neuroimmunomodulation: Molecular aspects, integrative systems, and clinical advances. Ann N Y Acad Sci, 840,1-1998 May 1

90. Dhabhar FS. Effects of stress on immune function: the good, the bad, and the beautiful. Immunol Res. 2014 May;58(2-3):193-210.

91. Walburn J, Vedhara K, Hankins M, Rixon L, Weinman J. Psychological stress and wound healing in humans: a systematic review and meta-analysis. J Psychosom Res. 2009 Sep;67(3):253-71.

92. Webster Marketon JI, Glaser R. Stress hormones and immune function. Cell Immunol. 2008 Mar-Apr;252(1-2):16-26.

93. Allen AP, Kennedy PJ, Cryan JF, Dinan TG, Clarke G. Biological and psychological markers of stress in humans: focus on the Trier Social Stress Test. Neurosci Biobehav Rev. 2014 Jan;38:94-124.

94. Pedersen AF, Zachariae R, Bovbjerg DH. Psychological stress and antibody response to influenza vaccination: a meta-analysis. Brain Behav Immun. 2009 May;23(4):427-33.

95. Pedersen A, Zachariae R, Bovbjerg DH. Influence of psychological stress on upper respiratory infection-a meta-analysis of prospective studies. Psychosom Med. 2010 Oct;72(8):823-32.

96. Bakunina N, Pariante CM, Zunszain PA. Immune mechanisms linked to depression via oxidative stress and neuroprogression. Immunology. $2015 \mathrm{Mar}$; 144(3): 365-373.

97. Hu D, Wan L, Chen M, Caudle Y, LeSage G, Li Q, Yin D. Essential role of IL-10/STAT3 in chronic stress-induced immune suppression. Brain Behav Immun. 2014 Feb; 36:118-127.

98. Cohen S, Janicki-Deverts D, Doyle WJ, Miller GE, Frank E, Rabin BS, et al. Chronic stress, glucocorticoid receptor resistance, inflammation, and disease risk. Proc Natl Acad Sci USA. 2012 Apr;109(16):5995-9. 
99. Lewis CE, O'Sullivan C, Barraclough J. The psychoimmunology of cancer: mind and body in the fight for survival? USA: Oxford University Press; 1994.

100. Peña J, Chen-Harris H, Allen JE, et al. Sendai virus intra-host population dynamics and host immunocompetence influence viral virulence during in vivo passage. Virus Evol. 2016 Jan; 2(1): vew008. Published online 2016 Apr 9. doi: 10.1093/ve/vew008

101. Schakel L, Veldhuijzen DS, Crompvoets PI, et al. Effectiveness of Stress-Reducing Interventions on the Response to Challenges to the Immune System: A Meta-Analytic Review. Published online 2019 Aug 6. doi: 10.1159/000501645: 10.1159/000501645

101. Al-Jasser FS, Nouh RM, Youssef RM. Epidemiology and predictors of survival of MERS-CoV infections in Riyadh region, 2014-2015. J Infect Public Health. 2019 Mar - Apr;12(2):171-177.

102. Bortz WMT, Bortz WM 2nd. How fast do we age? Exercise performance over time as a biomarker. J Gerontol A Biol Sci Med Sci. 1996; 51:M223-5.

103. Goldspink DF. Ageing and activity: Their effects on the functional reserve capacities of the heart and vascular smooth and skeletal muscles. Ergonomics. 2005;48:1334-51.

104. Sehl ME, Yates FE. Kinetics of human aging: I. Rates of senescence between ages 30 and 70 years in healthy people. J Gerontol A Biol Sci Med Sci. 2001; 56:B198-208.

105. Cinatl J, Morgenstern B, Bauer G, Chandra P, Rabenau H, Doerr HW. Glycyrrhizin, an active component of liquorice roots, and replication of SARSassociated coronavirus. Lancet 2003a;361:2045-6.

106. Jang WM, Cho S, Jang DH, et al. Preventive Behavioral Responses to the 2015 Middle East Respiratory Syndrome Coronavirus Outbreak in Korea. Int J Environ Res Public Health. 2019 Jun; 16(12): 2161.

107. Wu J and Zha P, Randomized Clinical Trial Is Biased and Invalid In Studying Chronic Diseases, Compared with Multiple Factors Optimization Trial (November 4, 2019). Available at SSRN: https://ssrn.com/abstract=3480523 or http://dx.doi.org/10.2139/ssrn.3480523.

108. A Multi-Factor Model for Estimating Relative Lifespans and Extending Health Spans https://www.researchgate.net/publication/337900952

109. Zhong NS, and Zeng GQ. Our Strategies for Fighting Severe Acute Respiratory Syndrome (SARS) All ajrccm Issues. Vol. 168, No. 1 Jul 01, 2003.

110. Zhang P, Li J, Liu $\mathrm{H}$ et al. Long-term bone and lung consequences associated with hospital-acquired severe acute respiratory syndrome: a 15-year 
follow-up from a prospective cohort study. Bone Research volume 8, Article number: 8 (2020)

111. Michiels, C. Physiological and Pathological Responses to Hypoxia. The American Journal of Pathology. 2004; 164 (6): 1875-82.

112. Lowen AC, Steel J. Roles of Humidity and Temperature in Shaping Influenza Seasonality. Journal of Virology. July 2014; 88:14,7692-7695.

113. Hemida MG. Middle East Respiratory Syndrome Coronavirus and the One Health concept. PeerJ 2019; 7: e7556.

114. Hussain S, Perlman S, Gallagher TM. Severe Acute Respiratory Syndrome Coronavirus Protein 6 Accelerates Murine Hepatitis Virus Infections by More than One Mechanism. J Virol. 2008 Jul; 82(14): 7212-7222.

115. Hussain S, Tom Gallagher. SARS-Coronavirus Protein 6 Conformations Required to Impede Protein Import into the Nucleus. Virus Res. Virus Res. 2010 Nov; 153(2): 299-304.

116. Wang H, Yuan X, Sun Y, Mao X, Meng C, Tan L, Song C, Qiu X, Ding C, Liao Y. Infectious bronchitis virus entry mainly depends on clathrin mediated endocytosis and requires classical endosomal/lysosomal system. Virology. 2019 Feb;528:118-136.

117. Baumann C, Neubert W. Neuraminidase-Deficient Sendai Virus HN Mutants Provide Protection from Homologous Superinfection, Archives of Virology, 2010;155: 217-27.

118. Xu R, Palmer SG, Porotto M, et al. Interaction Between the Hemagglutinin-Neuraminidase and Fusion Glycoproteins of Human Parainfluenza Virus Type III Regulates Viral Growth In Vivo, M Biology, 2013;4: e00803-13.

119. Houser KV, Broadbent AJ, Gretebeck L, et al. Enhanced inflammation in New Zealand white rabbits when MERS-CoV reinfection occurs in the absence of neutralizing antibody. PLoS Pathog. 2017 Aug; 13(8): e1006565. Published online 2017 Aug 17. doi: 10.1371/journal.ppat.1006565 